\title{
Activin A induces growth arrest through a SMAD- dependent pathway in hepatic progenitor cells
}

\author{
Lin Chen ${ }^{1 \dagger}$, Wei Zhang ${ }^{1 \dagger}$, Hui-fang Liang ${ }^{1 \dagger}$, Qiao-dan Zhou ${ }^{2}$, Ze-yang Ding ${ }^{1}$, Hong-qiang Yang ${ }^{1,3}$, Wei-bo Liu ${ }^{1}$,
} Yan-hui $\mathrm{Wu}^{1}$, Quan Man ${ }^{1}$, Bi-xiang Zhang ${ }^{1}$ and Xiao-ping Chen ${ }^{1 *}$

\begin{abstract}
Background: Activin A, an important member of transforming growth factor- $\beta$ superfamily, is reported to inhibit proliferation of mature hepatocyte. However, the effect of activin A on growth of hepatic progenitor cells is not fully understood. To that end, we attempted to evaluate the potential role of activin A in the regulation of hepatic progenitor cell proliferation.

Results: Using the 2-acetaminofluorene/partial hepatectomy model, activin A expression decreased immediately after partial hepatectomy and then increased from the 9th to 15th day post surgery, which is associated with the attenuation of oval cell proliferation. Activin A inhibited oval cell line LE6 growth via activating the SMAD signaling pathway, which manifested as the phosphorylation of SMAD2/3, the inhibition of Rb phosphorylation, the suppression of cyclinD1 and cyclinE, and the promotion of $\mathrm{p} 21^{\mathrm{WAF} / \mathrm{Cip}}$ and $\mathrm{p} 15^{\mathrm{INK} 4 \mathrm{~B}}$ expression. Treatment with activin A antagonist follistatin or blocking SMAD signaling could diminish the anti-proliferative effect of activin A. By contrast, inhibition of the MAPK pathway did not contribute to this effect. Antagonizing activin A activity by follistatin administration enhanced oval cell proliferation in the 2-acetylaminofluorene/partial hepatectomy model.
\end{abstract}

Conclusion: Activin A, acting through the SMAD pathway, negatively regulates the proliferation of hepatic progenitor cells.

Keywords: Hepatic progenitor cell, Activin A, follistatin, Proliferation, Smads protein

\section{Introduction}

Oval cells are regarded as adult liver progenitor cells. They are able to differentiate either into mature hepatocytes or biliary epithelial cells [1]. These cells are termed as "oval cells" due to their characteristic morphology with an ovoid nucleus, small size (relative to hepatocytes) and high nuclear to cytoplasmic ratio $[1,2]$. In the 2-acetaminofluorene (2-AAF)/partial hepatectomy ( $\mathrm{PH})$ model, hepatocyte proliferation is efficiently suppressed by 2-AAF. This forces liver regeneration to become dependent on the replication and differentiation of oval cells [3,4]. After the restoration of the normal liver mass, any excess oval cells that have failed to differentiate into mature hepatocytes stop

\footnotetext{
* Correspondence: chenxp@medmail.com.cn

${ }^{\dagger}$ Equal contributors

'Hepatic surgery centre, Tongji Medical College, Tongji Hospital, Huazhong University of Science and Technology, Wuhan, China

Full list of author information is available at the end of the article
}

replicating and are eliminated through apoptosis to prevent liver hyperplasia [5]. The complex molecular events that trigger liver regeneration are now beginning to be elucidated [6], but little is known about the mechanisms that restrict proliferation and return oval cell to quiescence after liver regeneration.

Transforming growth factor- $\beta 1$ (TGF- $\beta 1$ ) has been proposed to negatively regulate the proliferation of hepatocytes [7] and oval cells [8-10] but its role is controversial. TGF- $\beta 1$ over-expression results in impairment of oval cell expansion in vivo, inhibiting growth and inducing apoptosis in oval cell lines in vitro $[10,11]$. Conversely, other groups have demonstrated that TGF- $\beta 1$ signaling is not necessary for restricting hepatocyte proliferation [12]. Furthermore, compared to hepatocytes, hepatic progenitor cells (HPCs) are more resistant to the anti-proliferative effects of TGF- $\beta 1$ [9]. These data imply that there may be

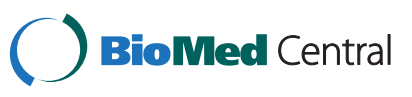


other factors that could recuperate the anti-proliferative effect of TGF- $\beta 1$ in the regulation of oval cell liver regeneration.

Activin A, composed of two activin- $\beta$ A subunits, is a member of the activin family, which in turn is part of the larger TGF- $\beta$ superfamily. Activin A binds to its specific activin type II receptors (ActRIIA and ActRIIB), which leads to the recruitment and trans-phosphorylation of the partner activin type I receptor (ALK4). Activated ALK4 recruits and phosphorylates cytoplasmic receptor-regulated SMADs (R-SMAD), SMAD2 and SMAD3, which form a heterotrimer with SMAD4 (co-SMAD) and translocate into the nucleus where they control gene transcription [13]. Activin A has been shown to suppress proliferation and induce apoptosis of mature murine hepatocytes in vivo and in vitro by up-regulating $\mathrm{p} 21^{\mathrm{WAF} 1 / \mathrm{Cip} 1}, \mathrm{p} 15^{\mathrm{INK} 4 \mathrm{~B}}$ and down-regulating cyclin D1 and Cyclin-Dependent Kinase expression, and dephosphorylating $\mathrm{Rb}$ [14-18]. Moreover, intravenous or intraportal administration of follistatin, a specific antagonist of activin A, can accelerate liver regeneration in partially hepatectomized rats [14-17]. Never-the-less, the role of activin A in the regulation of hepatic oval cell proliferation has yet to be fully elucidated. In order to reveal the action and mechanism of activin A on hepatic oval cell proliferation, we first tested the expression pattern of activin A and follistatin in the 2-AAF/PH model. We then evaluated the response of a hepatic oval cell line to activin A in vitro. Finally, we blocked activin A activity by intra-portal administration of follistatin in the 2-AAF/PH model, and measured hepatic oval cell proliferation to demonstrate that activin $\mathrm{A}$ is an important negative regulator of hepatic oval cell mediated liver proliferation.

\section{Results}

\section{Expression pattern of activin A and follistatin in 2-AAF/PH model}

We evaluated the spreading of HPCs in 2-AAF/PH model using immuno-histochemical staining for Pan-Cytokeratin (Pan-CK), which is an established marker of HPC's [18]. Recent studies have reported the activation of pan-CK positive HPCs in a number of HPC proliferation models including the 2-AAF/PH model [19-21]. In normal control and 2-AAF-treated sham operative rat liver, pan-CK mainly labeled interlobular and terminal duct cells. In the 2-AAF/PH model, high nuclei/cytoplasm ratio pan-CK positive cells (HPCs) initially appeared close to preexisting bile ducts in or around portal tracts (Figure 1B). These cells became more numerous with time and reached a peak on the 9th day after $\mathrm{PH}$ (Figure $1 \mathrm{C}$ and $\mathrm{M})$. From the 12 th day to the 15 th day post-surgery, the tubular structures and numbers of pan-CK positive cells dramatically decreased (Figure $1 \mathrm{D}$ and $\mathrm{M}$ ), reaching a nadir between the 18th day to 21st day post-surgery (Figure $1 \mathrm{M}$ ).

We next measured the expression of activin A and follistatin by immunohistology. Activin A expression showed no significant change until the 9th day, and then increased rapidly and reached a peak on the 12th day after surgery (Figure $1 \mathrm{~F}$ to $\mathrm{H}$ and $\mathrm{N}$ ). Follistatin level increased on the first day after surgery and was sustained until the 4th day (Figure 1J to $\mathrm{L}$ and $\mathrm{O}$ ).

The transcript level of activin $\beta A$ and follistatin mRNA did not vary dramatically in the sham operation group. Activin $\beta A$ mRNA production decreased below baseline from 6 hours to 9 days following $\mathrm{PH}(P<0.05)$, then increased from the 12th to 15 th day after surgery, when the number of pan-CK positive HPCs began to decline $(P<0.01)$ (Figure $1 \mathrm{P})$. Follistatin mRNA increased as soon as 6 hours after PH, $(P<0.05)$, and reached a peak at 24 hours $(P<0.05)$. After the peak, it declined below baseline from the 2nd day to 9th day after surgery $(P<0.01)$, then returned to the initial level on the 12th day (Figure 1Q). Activin $\beta$ A mRNA expression decreased and its endogenous antagonist follistatin increased during the first phase of HPC dependent liver regeneration, while HPCs dramatically proliferated. At the end of the second week, the increase in activin $\beta A$ expression coincided with the decline in HPCs. From these data, we presume that the activin $\mathrm{A}$ /follistatin axis may play an important role in the regulation of HPCs after partial hepatectamy.

\section{Activin A suppresses HPCs proliferation in vitro}

In order to confirm our hypothesis, we tested the effect of exogenous activin A on cells from the rat HPC cell line LE6. First, we examined the baseline of endogenous activin $A$ and TGF- $\beta 1$ in LE6 cells by enzymelinked immunosorbent assay (ELISA). Any activin A secreted by LE6 cell cultures was below the minimum detectable dose of the ELISA kit (data not shown). LE6 cells secreted detectable quantities of TGF- $\beta 1$ which amounted to $60 \mathrm{pg} / \mathrm{ml}$ in the culture supernatants, and the addition of exogenous activin A to the cell cultures did not alter their expression of either activin $A$ or TGF- $\beta 1$ (Figure 2A). Therefore, we could ignore the interference of endogenous activin $\mathrm{A}$ and TGF- $\beta 1$. Next, we treated LE6 cells with various doses of exogenous activin A and measured the effect of this cytokine on LE6 cell proliferation. As cell counting kit-8 (CCK-8) assay results showed in Figure $2 \mathrm{~B}$, activin $\mathrm{A}$ significantly inhibited proliferation of LE6 cells in a dose-dependent manner. Over a $72 \mathrm{~h}$ incubation period, $25 \mathrm{ng} / \mathrm{ml}$ activin A was sufficient to induce growth inhibition in LE6 cells. A maximum of $40 \%$ inhibition of proliferation was achieved with $200 \mathrm{ng} / \mathrm{ml}$ activin A. Accordingly, BrdU label index assay showed 200 ng/ml 


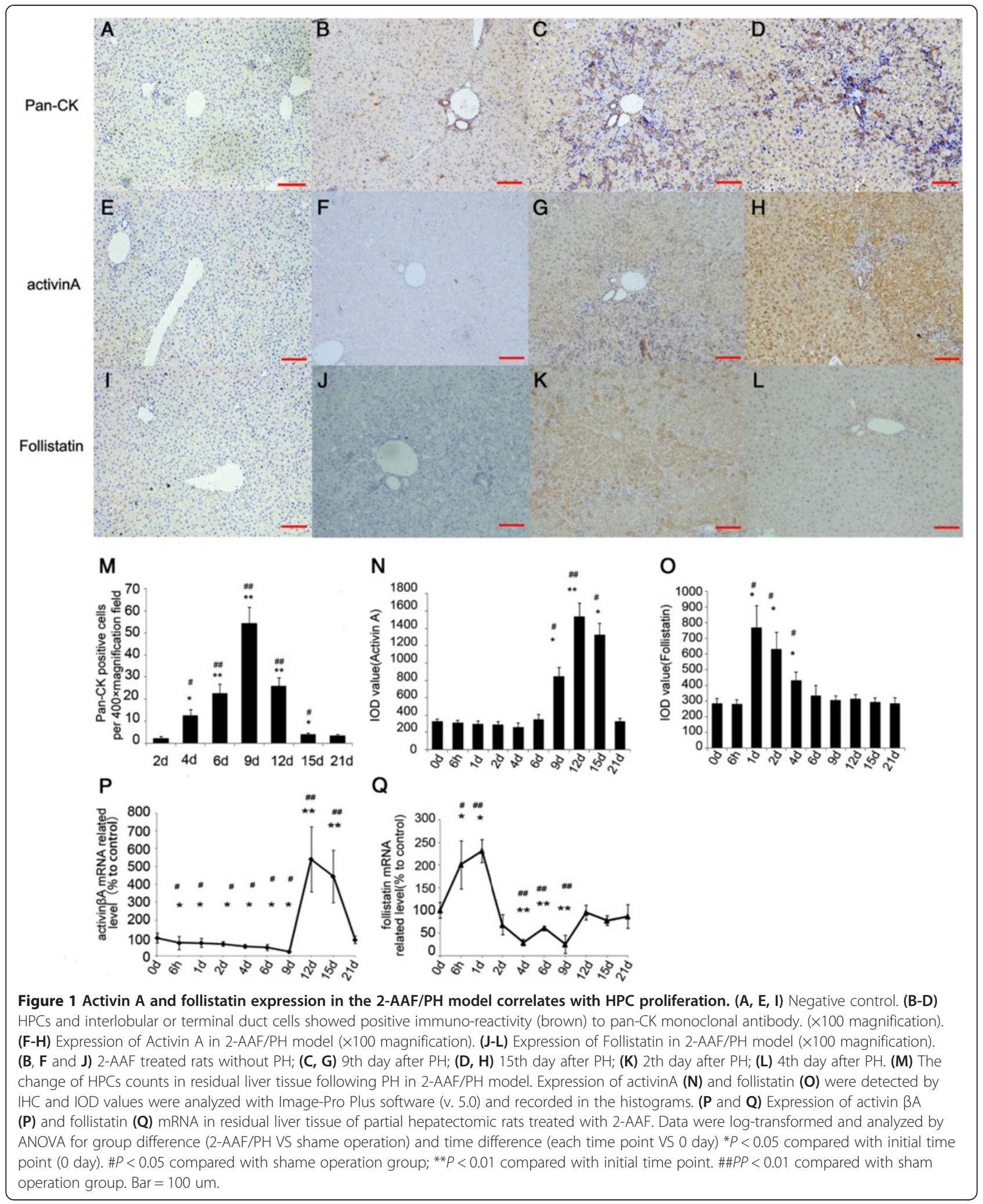

activin A inhibited as much as about 50\% DNA synthesis in LE6 cells (Figure 2C). We next explored the effect of activin treatment on induction of apoptosis in LE6 cells using an AnnexinV/PI double label assay. As seen in Figure 2D, $200 \mathrm{ng} / \mathrm{ml}$ activin A barely induced apoptosis in LE6 cells (Figure 2D). 
A

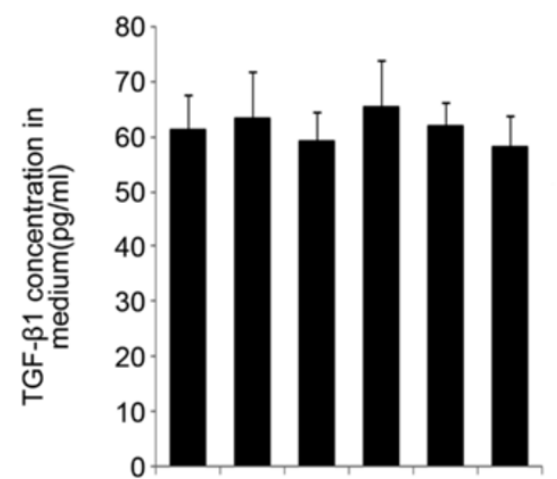

$\operatorname{activin} \mathrm{A}(\mathrm{ng} / \mathrm{ml}) 0$

C
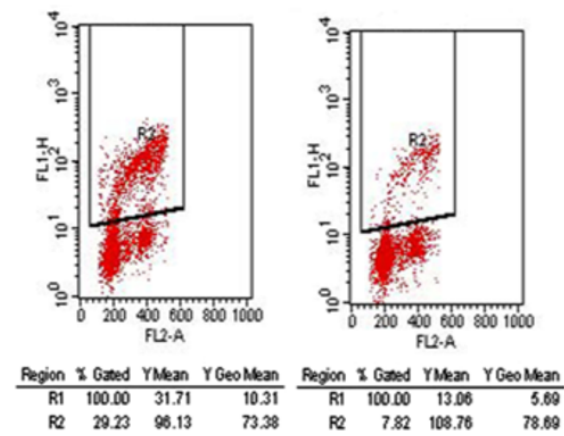

D
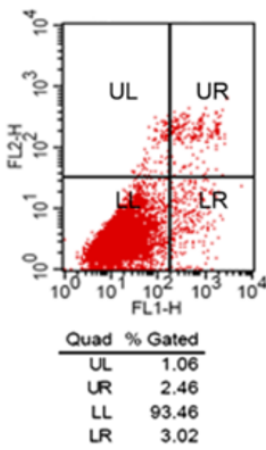

B
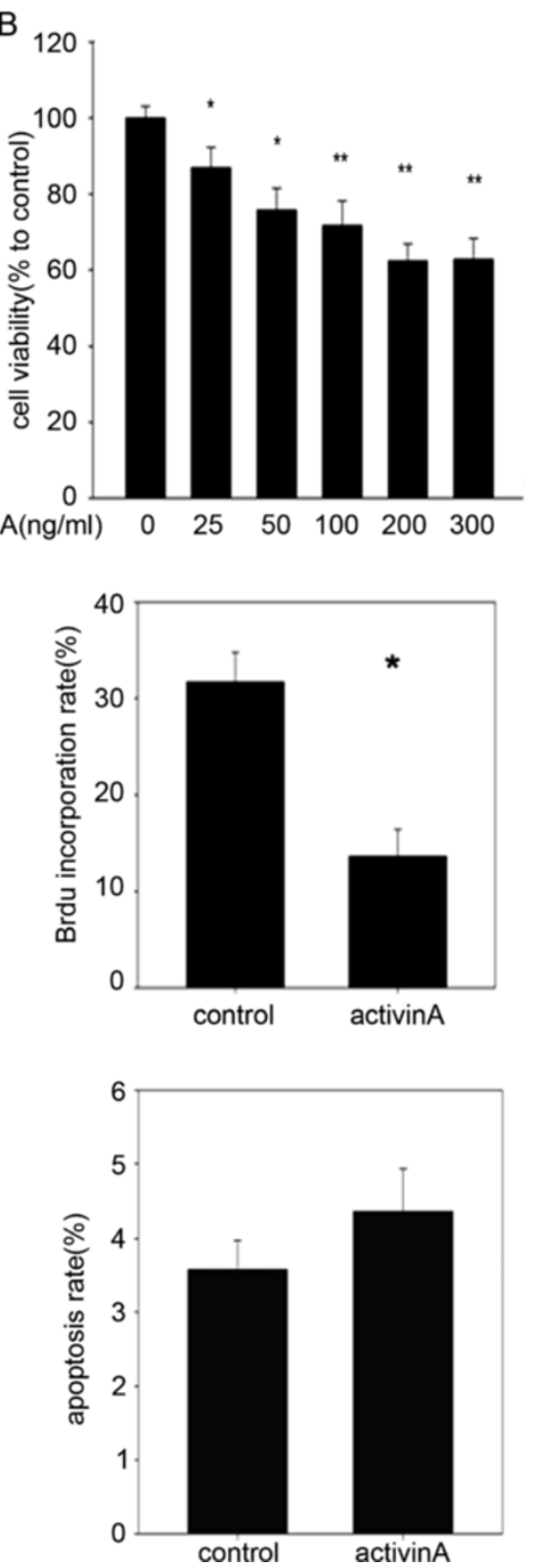

Figure 2 Activin A inhibited proliferation of LE6 cells. (A) $2 \times 10^{5}$ LE6 cells/ were seed into 6-well plate and treated with serum free LE media in the present of activin A for up to 48 hours. Cell media was harvested and concentration of TGF- $\beta 1$ was detected by ELISA kit. The figure showed result of one of three independent assays (B) LE6 cells were grown in 8\% FBS LE media in the present or absence of activin A (25, 50, 100, 200, $300 \mathrm{ng} / \mathrm{ml}$ ) for 72 hours. Cell proliferation was assessed by CCK-8 assay. Data showed result of one of three independent assays. (C and D) LE6 cells were grown in 8\% FBS LE media in the presence or absence of activin A ( $200 \mathrm{ng} / \mathrm{ml})$ for 72 hours. Cell DNA synthesis was assessed by BrdU incorporation assay using FACS (C). R2 = BrdU positive cells. Cell apoptosis was assessed by AnnexinV/PI assay using FACS (D). LL = Live cells or annexin $\mathrm{V}$ and $\mathrm{PI}$ negative cells, $\mathrm{LR}=$ Early apoptotic cells or annexin $\mathrm{V}$ positive cells, UR= Late apoptotic and necrotic cells or annexin $\mathrm{V}$ and PI positive cells, $U L=$ Necrotic cells or PI positive cells. Bar chart showed the apoptosis rate $(U R+L R)$ of control and activin treated LE6 cells. The figure showed result of one of three independent assays.

Rb protein, cyclinD1, cyclinE, p15 $5^{\mathrm{INK} 4 \mathrm{~B}}$ and $\mathrm{p} 21^{\mathrm{WAF} 1 / \mathrm{Cip} 1}$ are involved in activin A induced growth arrest in LE6 cells

To investigate the mechanism underling activin Ainduced growth arrest in LE6 cells, we treated LE6 cells with activin A and detected a series of cell cycle related proteins by western-blot. As shown in Figure 3A, the protein expression of the cyclin dependent kinase inhibitors $\mathrm{p} 15^{\mathrm{INK} 4 \mathrm{~B}}$ and $\mathrm{p} 21^{\mathrm{WAF} 1 / \mathrm{Cip} 1}$ increased dramatically after 

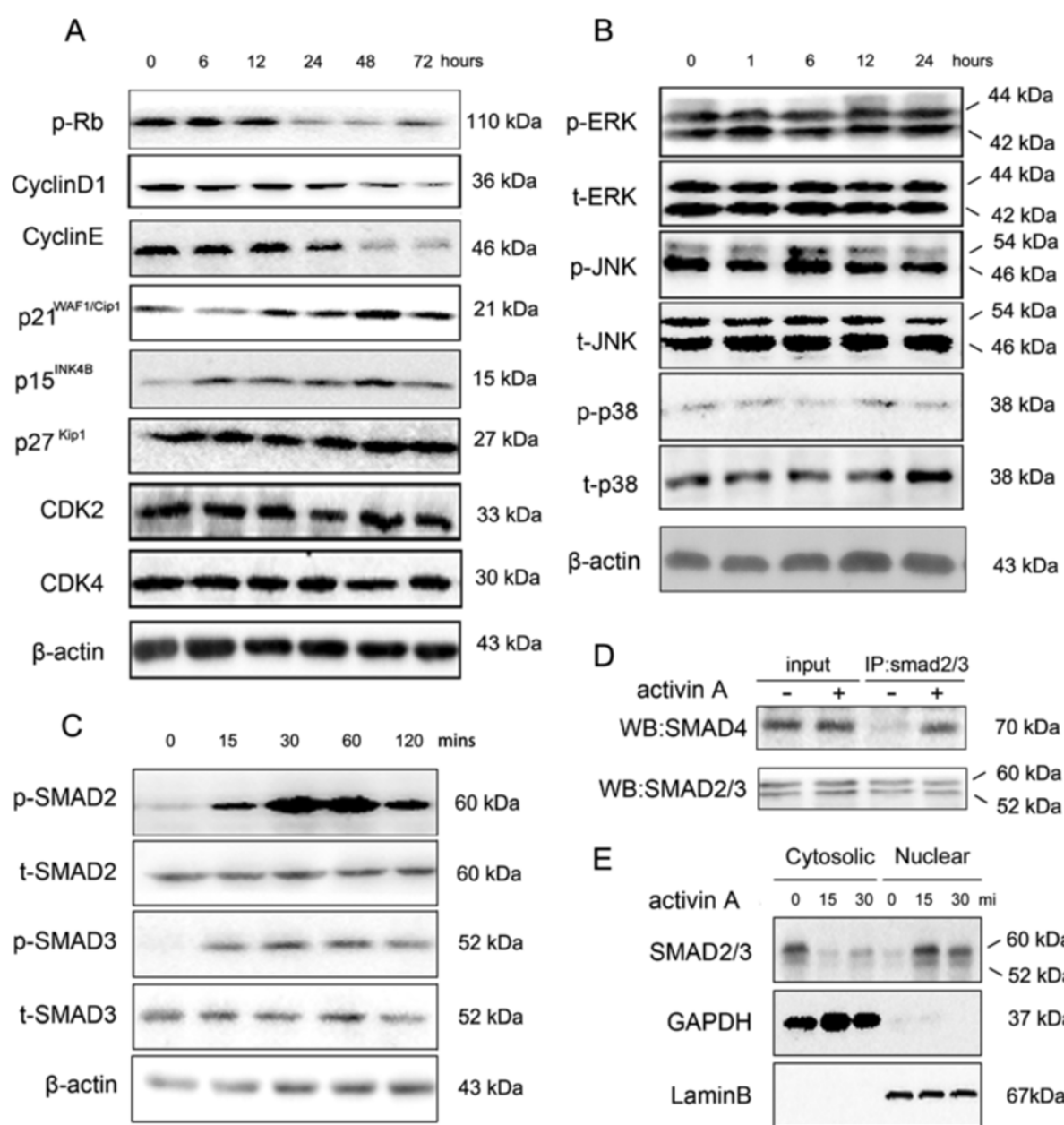

E

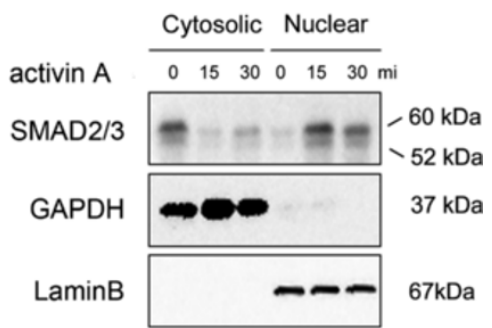

Figure 3 Activin A activates SMAD signaling in LE6 cells. (A) LE6 cells were treated with activin A (200 ng/ml) for $6 \mathrm{~h}, 12 \mathrm{~h}, 24 \mathrm{~h} 48 \mathrm{~h}$ and $72 \mathrm{~h}$, cell lysis was analyzed by western-blot using specific antibody to phosphorylated Rb, cyclinD1, cyclinE, p21 WAF1/Cip1, p1 $5^{\text {INK } 4 \mathrm{~B}} \mathrm{p} 27^{\text {Kip } 1}, \mathrm{CDK} 2$ and CDK4. $\beta$-actin was used as a loading control. (B) LE6 cells were treated with activin A (200 ng/ml) for 1 h, 6 h, 12 h and 24 h, cell lysis was analyzed by western-blot using specific antibody to phosphorylated JNK1/2, ERK1/2 and p38. (C) LE6 cells were treated with activin A (200 ng/ml) for $15 \mathrm{~min}, 30 \mathrm{~min}, 60 \mathrm{~min}$ and $120 \mathrm{~min}$, cell lysis was analyzed by western-blot using specific antibody to phosphorylated SMAD2, SMAD3. (D) LE6 cells were treated with activin A (200 ng/ml) for $60 \mathrm{~min}$, cell lysis was incubated with anti-SMAD2/3 antibody and protein A/G agarose overnight, then analyzed by western-blot using specific antibody to SMAD4. (E) LE6 cells were treated with activin A (200 $\mathrm{ng} / \mathrm{ml})$ for 15 min and 30 min, Nuclear and cytosolic fractions of cells were analyzed by western-blot using specific antibody to SMAD2/3.GAPDH or laminB was used as loading control for cytosolic or nuclear fraction.

$6 \mathrm{~h}$ and $12 \mathrm{~h}$ respectively, and in both cases this was sustained until $72 \mathrm{~h}$ after activin A stimulation. Conversely, cyclin D1 and cyclin E expression decreased significantly 24 hours after exposure to activin A. Moreover, phosphorylation of $\mathrm{Rb}$ was also inhibited by activin A. By contrast, activin A stimulation was unable to affect the extent of $\mathrm{p} 27^{\mathrm{Kip}}$, cyclindependent kinase 2 (CDK2) and cyclin-dependent kinase 4 (CDK4) expression in LE6 cells. These results indicated that activin A suppressed downstream targets cyclin D1 and cyclin E, induced expression of $\mathrm{p} 21^{\mathrm{WAF} 1 / \mathrm{Cip} 1}$ and $\mathrm{p} 15^{\mathrm{INK} 4 \mathrm{~B}}$, and dephosphorylated Rb protein all of which are likely to contribute to cell growth arrest.

\section{Activin A failed to activate SMAD-independent}

mitogen-activated protein kinase signaling in LE6 cells

Next we investigated the signaling pathways, activated by activin $\mathrm{A}$, that are required for growth arrest. The principal pathways include the SMAD and mitogenactivated protein kinase (MAPK) signaling cascades [22]. First, we investigated the MAPK pathway by measuring phosphorylated ERK1/2, JNK1/2 and p38MAPK in LE6 cells by western-blot (Figure 3B). In the absence of activin A stimulation, all three kinases were constitutively phosphorylated in LE6 cells, and their phosphorylation was not affected by activinA treatment. These data suggest that MAPK signaling did not contribute to activinA induced growth arrest in LE6 cells. 


\section{SMAD dependent signaling is necessary for activin A induced growth arrest in HPCs}

Next we looked at the SMAD pathway. LE6 cells were incubated with the indicated dose of activin $\mathrm{A}$, and then phosphorylated SMAD2 and SMAD3 were analyzed by western-blot. The data showed that SMAD2 and SMAD3 were phosphorylated in a time-dependent manner (Figure 3C). Phosphorylated SMAD2/3 forms a complex with SMAD4 that shuttles into nucleus where they regulate downstream gene transcription [22]. We detected the formation and location of SMAD2/3/4 heterotrimer in activin A treated LE6 cells. The co-immunoprecipitation (co-IP) results demonstrated activin A induced SMAD2/ 3/4 complex formation in LE6 cells (Figure 3D) and western-blot results indicated that SMAD2/3 was predominantly located in nucleus in activin A treated LE6 cells, while conversely, SMAD2/3 was principally located in cytoplasm in control cells (Figure 3E). These data confirm that activin $\mathrm{A}$ is able to activate the canonical SMAD signaling pathway in LE6 cells.

\section{SMAD4 knockdown interrupts activin A-induced growth arrest in LE6 cells}

SMAD4 is the pivotal factor of canonical SMAD signaling and its inactivation or deletion prevents SMAD signaling. To further investigate the role of the SMAD pathway in activin A-mediated growth arrest, LE6 cells were infected with LV-shSmad4 to stable knockdown endogenous Smad4. 3 of 4 Smad4 shRNA oligonucleoties were able to deplete Smad4 expression by more than $70 \%$ in LE6 cells and we chose the most effective sequence sh3 for the following study (Figure 4A). Activin A stimulated SMAD2 and SMAD3 phosphorylation (Figure 4B) but failed to induce formation of functional SMAD2/3/4 heterotrimer in Smad4 knockdown LE6 cells (LE6-Smad4KD) (Figure 4C). These data indicated that activin A-induced SMAD signaling could be blocked by Smad4 knockdown.

We next explored the effect of depleting SMAD4 on the ability of activin A to induce a growth arrest. LE6 cells transferred with an empty vector remained sensitive to the effects of activin A, whereas LE6-Smad4KD were resistant to activin A induced growth inhibition. Then we examined the effect of activin A on the target protein expression in LE6-Smad4KD cells (Figure 4E). As expected, activin A induced expression of p21 WAF1/ ${ }^{\mathrm{Cip} 1}$ and $\mathrm{p} 15^{\mathrm{INK} 4 \mathrm{~B}}$ in LE6-wild type (LE6-WT) cells, but it could not induce these proteins in LE6-Smad4KD cells. Consistent with this, activin A failed to downregulate cyclin $\mathrm{E}$, or cyclin $\mathrm{D} 1$, or phosphorylated $\mathrm{Rb}$ in LE6-Smad4KD cells. These results confirmed that SMAD4-dependent signaling was crucially involved in activin A induced growth inhibition in HPCs.

\section{Follistatin antagonizes activin A induced growth arrest in HPCs}

We found that follistatin mRNA increased in the early phase of HPC-mediated liver regeneration, which was about $6 \mathrm{~h}$ after $\mathrm{PH}$ and was followed by HPC proliferation. These data indicated that follistatin could interrupt the tonic growth inhibitory effect of activin A and in turn stimulate HPC-induced liver regeneration. To confirm this hypothesis, we treated LE6 cells with either activin A, or activin A together with increasing-doses of follistatin or follistatin alone, then analyzed the proliferation using CCK- 8 and BrdU incorporation assay. As seen in Figure 5A and B, $400 \mathrm{ng} / \mathrm{ml}$ follistatin could fully reverse $200 \mathrm{ng} / \mathrm{ml}$ activin A-induced growth arrest in LE6 cells. Nevertheless, follistatin alone was unable to regulate cell proliferation. Yet, follistatin therapy completely inhibited activin Ainduced phosphorylation of SMAD2 and SMAD3, restored expression of cyclin D1 and cyclin E suppressed by activin $\mathrm{A}$ and suppressed $\mathrm{p} 21^{\mathrm{WAF} 1 / \mathrm{Cip} 1}$ and $\mathrm{p} 15^{\mathrm{INK} 4 \mathrm{~B}}$ expression induced by activin A (Figure 5C and 5D). These data indicated that follistatin could inhibit activin A induced growth arrest.

\section{Follistatin boosts HPC proliferation in vivo}

In order to confirm the anti-proliferation role of activin A in vivo, follistatin or normal saline (NS group) was infused into portal vein immediately after $70 \% \mathrm{PH}$ and into the tail vein at 5, 10, 15 and 20 days after $\mathrm{PH}$ in 2$\mathrm{AAF} / \mathrm{PH}$ rats. Compared to the NS group, more Pan-CK positive hepatic progenitor cells were present in follistatintreated rats at $6,9,12,15$ days after $\mathrm{PH}$. However, no significant differences were detected in rats at 4 days and 21 days after PH (Figure 6B, 6C and 6G). Next we detected the proliferation of cells in both groups by BrdU label assay. More BrdU-positive cells were detected in the follistatintreated group at 4, 9, 12 days after $\mathrm{PH}$. In addition, there were no significant differences between these 2 groups at 15 and 21 days after PH (Figure 6E, 6F and 6H). To exclude potential errors from body weight variations, liver/body weight ratios were used to assess remnant liver restoration. The ratio in the follistatin treated group was dramatically higher than NS group at 9 days, 12 days and 15 days after PH (Figure 6I). These data indicate that follistatin, an activin A antagonist, could enhance and prolong hepatic progenitor cell amplification in vivo. These results confirmed the anti-proliferation effect of activin A on hepatic progenitor cells in vivo.

\section{Discussion}

In the present study, we examined the inhibitory effect of activin A on the proliferation of hepatic progenitor cells and revealed the mechanism. Activin A has been previously reported to inhibit DNA synthesis in mature hepatocytes [12,15-17,23,24]. After 2/3 PH, activin A expression 


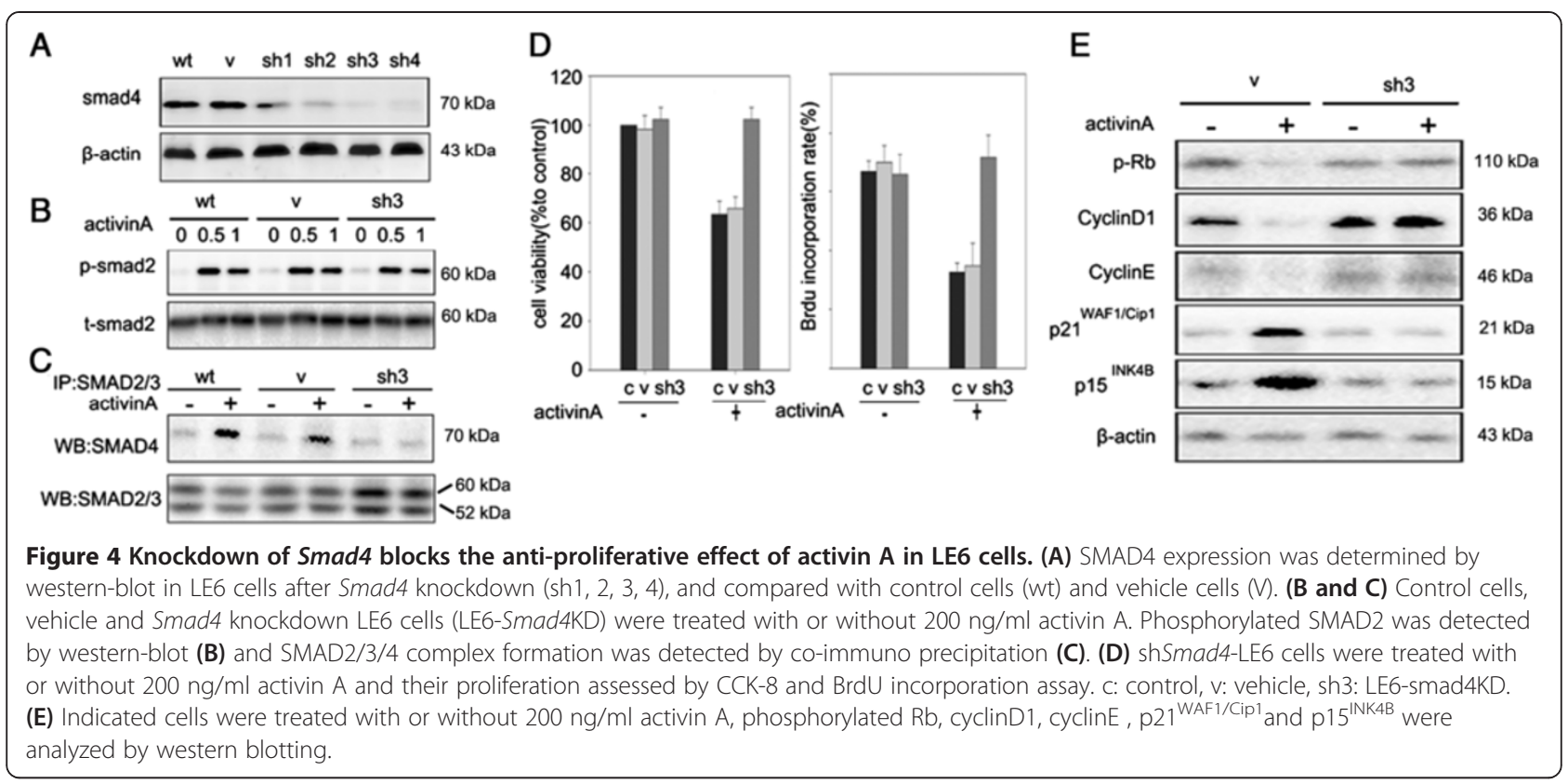

is decreased and follistatin is induced during the growth period, whereas activin A expression is significantly induced in the later stages when regeneration is slowing down [25]. We observed a similar behavior in the 2-AAF/ PH HPC-mediated liver regeneration model. Furthermore, DNA synthesis was enhanced in intact rat liver in which activin A signaling was temporary disrupted by administration of follistatin [26-28]. Our data demonstrated follistatin enhanced proliferation of HPCs in the 2-AAF/PH model. All these findings indicate that a basal amount of activin A exists in the intact liver to tonically inhibit mature hepatocyte or HPC-mediated proliferation and maintained adequate liver weight. Moreover, it plays an important role in termination of liver regeneration. Once the balance between follistatin and activin A is broken, for example, in the $\mathrm{PH}$ or 2-AAF/PH model, hepatocyte or hepatic progenitor cells escape from the anti-proliferative effect of activin A and start to proliferate. Once the liver mass is restored, the restoration of activin A expression again terminates liver regeneration, irrespective of whether the regeneration is mediated by hepatocytes or hepatic progenitor cells.

Ooe et al. [29] described a subpopulation of rat hepatocytes (small hepatocyte, $\mathrm{SH}$ ) that have high growth potential in culture. Recent studies indicated that $\mathrm{SH}$ are posterity of oval cells: Ichinohe and Xiang reported that oval cells could differentiate into mature hepatocyte via SH [30-32]. Consistent with our work, Ooe found activin A suppresses the proliferation of $\mathrm{SH}$, but cannot induce apoptosis of $\mathrm{SH}$. Both studies demonstrate that the activin pathway is a key negative regulator of hepatic progenitor proliferation. However, Ooe reported activin B suppressed the proliferation of $\mathrm{SH}$ in an autocrine manner. The contribution of activin B and other members of the activin family to the proliferation of oval cells needs further investigation. Menthena et al. [33] reported fetal liver progenitor cells were resistant to activin A because of their lack of activin A receptors. The inconsistency between both Menthena and Ooe's studies and our results may be due to different activin A receptor expression. In our hands and in Ooe's work activin receptors are abundantly expressed in adult hepatic progenitor cells. This fact suggests that there are major differences in the regulation of cell growth between adult and fetal liver progenitor cells.

The anti-proliferative effects of activin A are likely to be due to the activation of signaling pathways that target cell cycle-related proteins. Activin A enhanced expression of $\mathrm{p} 15^{\mathrm{INK} 4 \mathrm{~B}}$, reduced cyclin $\mathrm{A}$ expression and reduced phoshorylation of the $\mathrm{Rb}$ protein in breast cancer cells [34]. Hepatoma cells respond to activin by upregulating the expression of $\mathrm{p} 21^{\mathrm{WAF} 1 / \mathrm{Cip} 1}, \mathrm{p} 16$ and $\mathrm{p} 15^{\mathrm{INK} 4 \mathrm{~B}}$ proteins that suppress the cyclinD-CDK4/6 and cyclinE-CDK2-mediated phosphorylation of the Rb protein $[23,35,36]$. Activin A could down-regulate cyclin $\mathrm{D}$, cyclin $\mathrm{E}$ and CDK4, all of which are important contributors to $\mathrm{Rb}$ protein phosphorylation $[34,36]$. The dephosphorylation of $\mathrm{Rb}$ leads to cell cycle arrest and inhibtion of cell proliferation. Our study demonstrated that activin A stimulated the expression of $\mathrm{p} 15^{\mathrm{INK} 4 \mathrm{~B}}$ and $\mathrm{p} 21^{\mathrm{WAF} 1 / \mathrm{Cip} 1}$ and inhibited the expression of cyclin $\mathrm{D} 1$ and cyclin $\mathrm{E}$ protein leading to the inhibition of $\mathrm{Rb}$ protein phosphorylation. These data indicated that $\mathrm{p} 15^{\mathrm{INK} 4 \mathrm{~B}}, \mathrm{p} 21^{\mathrm{WAF} 1 / \mathrm{Cip} 1}$, cyclin D1 and cyclin E were all associated with regulating the degree of $\mathrm{Rb}$ protein phosphorylation during activin A-induced cell proliferation arrest in HPCs. 

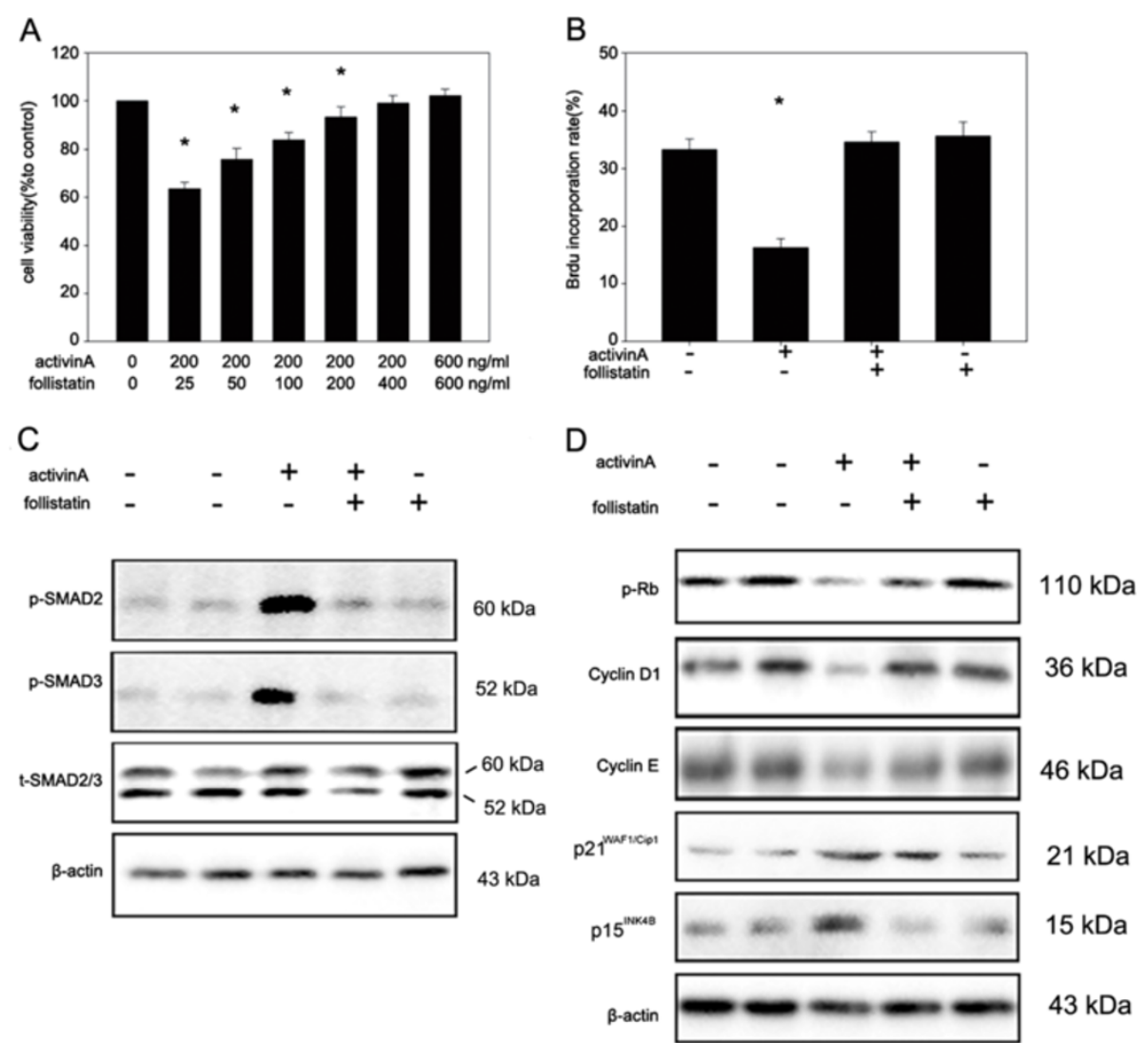

Figure 5 Follistatin blocks the growth arrest induced by activin A in LE6 cells. (A) LE6 cells were treated with activin A (200 ng/ml) in the presence or absence of the indicated doses of follistatin $(25,50,100,200,400,600 \mathrm{ng} / \mathrm{ml}$ ). Cell proliferation was detected by CCK-8 assay. (B) LE6 cells were grown in LE media in the presence or absence of activin A $(200 \mathrm{ng} / \mathrm{ml})$, follistatin $(400 \mathrm{ng} / \mathrm{ml})$ or activin A $(200 \mathrm{ng} / \mathrm{ml})$ plus follistatin ( $400 \mathrm{ng} / \mathrm{ml}$ ). DNA synthesis was detected by BrdU incorporation assay using FACS. (C) LE6 cells were treated with or without activin A (200 ng/ml), follistatin $(400 \mathrm{ng} / \mathrm{ml})$ or activin A (200 ng/ml) plus follistatin $(400 \mathrm{ng} / \mathrm{ml})$ for $30 \mathrm{~min}$. Phosphorylated SMAD2/3 was detected by western-blot. (D) LE6 cells were treated with either media alone, activin A $(200 \mathrm{ng} / \mathrm{ml})$, follistatin $(400 \mathrm{ng} / \mathrm{ml})$ or activin $(200 \mathrm{ng} / \mathrm{ml})$ plus follistatin $(400 \mathrm{ng} / \mathrm{ml})$. Then phosphorylated Rb, cyclinD1, cyclinE, p21 ${ }^{\text {AAF1/Cip } 1}$ and $p 15^{\text {INK } 4 \mathrm{~B}}$ were analyzed by western-blot.

Activin A regulates cell proliferation in numerous types of cells via SMAD signaling. The activation of the activin A/SMAD pathway results in the formation and nuclear location of the SMAD2/3/4 complex and regulates the expression of known targets including c-myc, cdc25A, $\mathrm{p} 15^{\mathrm{INK} 4 \mathrm{~B}}, \mathrm{p} 21^{\mathrm{WAF} 1 / \mathrm{Cip} 1}, \mathrm{p} 16^{\text {INK4A }}$, cyclinA, cyclinD1 and cyclinE [37-39]. However, other studies reported that not only SMAD, but also p38MAPK and ERK signaling contribute to activin A-induced proliferation arrest or apoptosis $[40,41]$. Our study confirmed that activin A activated SMAD pathway (SMAD2/3 phosphorylation, SMAD2/3/4 complex formation and nuclear location), and regulated downstream targets expression (p15 $5^{\mathrm{INK} 4 \mathrm{~B}}, \mathrm{p} 21^{\mathrm{WAF} 1 / \mathrm{Cip} 1}$, cyclin D1 and cyclin E) in HPCs. Destruction of SMAD signaling by SMAD4 knockdown fully restrained activin A-induced proliferation arrest in LE6 cells. Moreover, activin A failed to change the phosphorylation level of p38 and ERK in LE6 cells. These data indicate that the anti-proliferation effect of activin A is SMADdependent. Nevertheless, we noticed a high basal level of phosphorylated p38, ERK and JNK in serum-starved LE6 cells, which might be related to the autocrine production of growth/survival factors, such as hepatocyte growth factor (HGF) and epidermal growth factor (EGF). These autocrine signals may be responsible for the insensitivity of MAPK pathways to respond to the addition of exogenous activin A. Furthermore, the over-activation of MAPK might be also responsible for our observation that LE6 cells were more insensitive to activin A-induced growth arrest and apoptosis compared to previously reported studies in mature hepatocytes [35,42].

The biological function of follistatin has been based on its reported ability to bind to activins with a high affinity. The picomolar affinity of follistatin molecules for activin dimmers forms the basis for follistatin to act as a potent extracellular regulatory mechanism in which activins are tightly bound and cannot bind to activin receptors and trigger downstream signaling [43]. Ooe et al. reported follistatin facilitates the proliferation of small hepatocytes by blocking activin A signaling in an autocrine manner. 


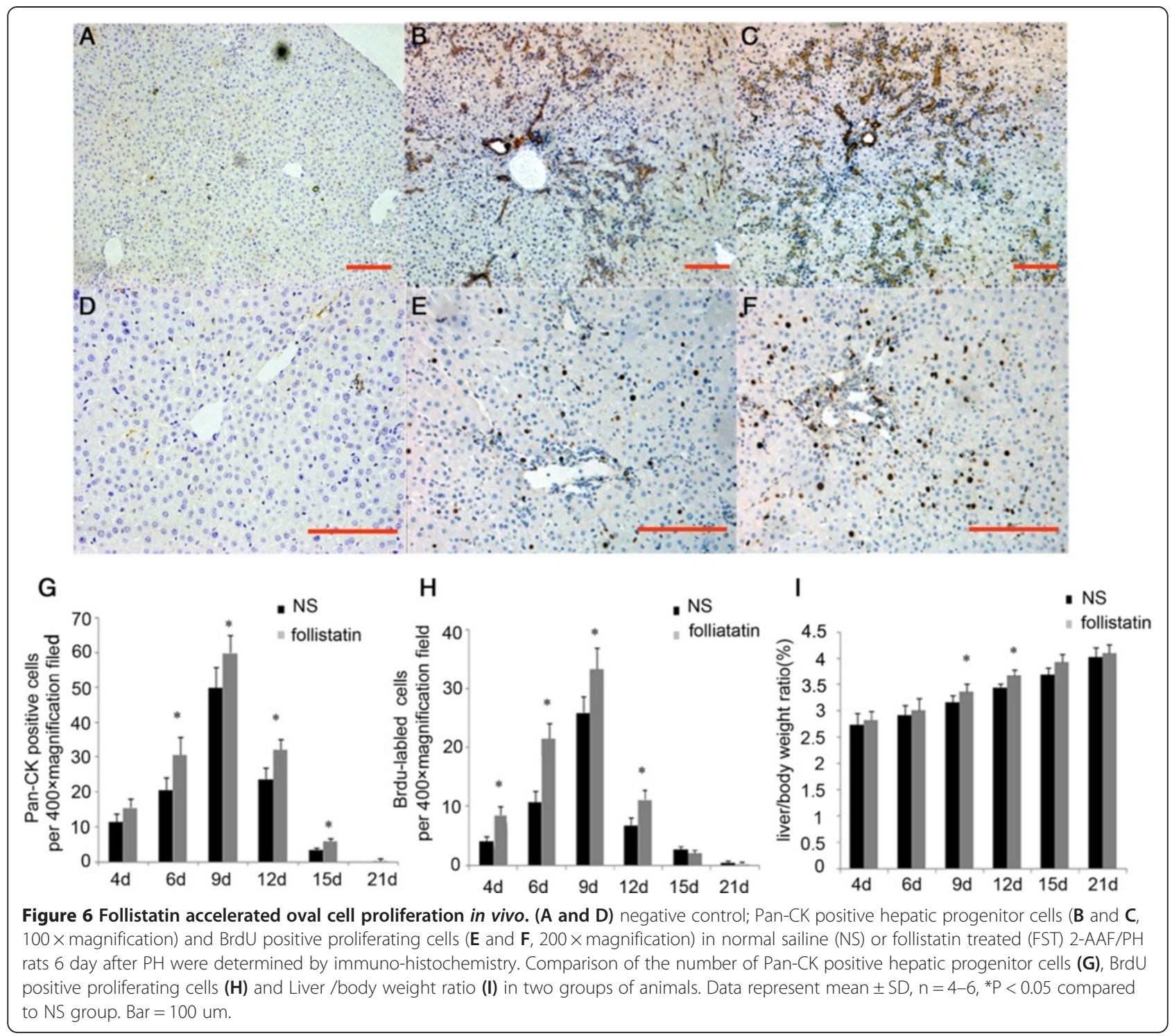

Administration of follisatin accelerated proliferation of hepatocyte growth in vivo. In the 2-AAF/PH model, upregulation of follistatin in rat livers decreased the activity of activin A signaling and rendered cells resistant to activin A-induced growth arrest. Administration of follistatin accelerated oval cell expansion in the 2-AAF/PH model. Yet, follistatin alone was unable to affect the proliferation of LE6 cell. Taken together, our data indicated follistatin regulated oval cell proliferation only by blocking activin A. Our data also indicated that although follistatin itself did not have the ability to work as mitogen, it could neutralize the growth arrest of activin A and facilitated the proliferation of hepatic progenitor cells.

In conclusion, our study showed the compact correlation between activin A signaling and HPC proliferation. Furthermore, we found activin A inhibited cellular proliferation in HPC cell lines via the canonical SMAD pathway. Activin A up-regulated $\mathrm{p} 15^{\mathrm{INK} 4 \mathrm{~B}}$ and $\mathrm{p} 21^{\mathrm{WAF} 1 / \mathrm{Cip} 1}$, down-regulated cyclin D1 and cyclin E. Consistent with our results, it is reported that reduced phosphorylation of $\mathrm{Rb}$ protein, is associated with a growth arrest in HPCs. Taken together, activin A plays an important role in negative regulation of HPCs proliferation through a SMAD-dependent pathway.

\section{Material and methods} Animal model

Adult male Sprague-Dawley rats (180-200 g) were used. They were bred and maintained on standard laboratory chow using 12-hour light/dark cycles. The body weights were recorded daily. The rats were treated according to the guidelines of the council for International Organizations of Medical Sciences, as required by the ethics committee of Tongji Medical College. 
The rats 2-AAF/PH model were made as previously described [44]. Briefly, all rats received oral gavages of 2AAF (Sigma-Aldrich MO USA) dissolved in polyethylene glycol (mol. wt. 400, Sigma-Aldrich MO USA) for up to 11 days at the dose of $15 \mathrm{mg} / \mathrm{kg}$, and then two-thirds $\mathrm{PH}$ was performed under pentobarbitone anaesthesia in the fifth day. Control sham operation consisted of laparotomy without $\mathrm{PH}$ and briefly handling the liver. Five rats were killed at $6 \mathrm{~h}, 1 \mathrm{~d}, 2 \mathrm{~d}, 4 \mathrm{~d}, 6 \mathrm{~d}, 9 \mathrm{~d}, 12 \mathrm{~d}, 15 \mathrm{~d}$ and $21 \mathrm{~d}$ after initiation of PH. Liver tissue samples were fixed in $4 \%$ paraformaldehyde and processed to $4 \mu \mathrm{m}$ thick sections for immunohistochemistry or immediately stored in $-80^{\circ} \mathrm{C}$ for real-time PCR.

\section{Follistatin administration}

After $70 \%$ PH, 1microgram follistatin dissolved in $0.5 \mathrm{ml}$ natural saline was infused into portal vein using $29 \mathrm{G}$ insulin syringe as mentioned by Kogure [14]. In the normal saline (NS) group, the same volume of normal saline was infused into portal vein. The same dose of follistatin or saline was injected into tail vein at 5, 10, 15 and 20 days after PH.4-6 rats were killed at 4d, 6d, 9d, 12d, 15d, 21d after initiation of $\mathrm{PH}$, liver weights and body weights were recorded. Restoration of liver weights was expressed as percentage of regenerated liver weight to body weight. For BrdU incorporation assay, two hours before sacrifice, animals were injected intraperitoneally with $50 \mathrm{mg} 5$ bromo-2-deoxyuridine (BrdU) per kg body weight. Liver tissue samples were fixed in $4 \%$ paraformaldehyde for immunohistochemistry.

\section{Immunohistochemistry}

Sections were deparaffinised as described previously. Antigens were retrieved by incubating with proteinase $\mathrm{K}$ (DakoCytomation, Glostrup, Denmark) at $4^{\circ} \mathrm{C}$ for $5 \mathrm{~min}$ or by undergoing microwave heat antigen retrieval in $10 \mathrm{mM}$ Tris Base, $1 \mathrm{mM}$ EDTA Solution, $\mathrm{pH}$ 9.0; For BrdU incorporation assay, sections were incubated in $4 \mathrm{~N}$ $\mathrm{HCL}$ for $20 \mathrm{~min}$ at $37^{\circ} \mathrm{C}$, after rinsing in $0.1 \mathrm{M}$ borax solution for $5 \mathrm{~min}$ and PBS for $3 \times 5 \mathrm{~min}$, sections were incubated with $0.1 \%$ trypsin for $10 \mathrm{~min}$ at $37^{\circ} \mathrm{C}$. Endogenous peroxidase activity was blocked with $3 \% \mathrm{H}_{2} \mathrm{O}_{2}$ in methanol. Then sections were incubated with rabbit antipan-cytokeratin antibody (1:50, DAKO, Denmark), mouse anti-activin A antibody (1:100, R\&D, USA), rabbit antifollistatin antibody (1:50, ProteinTech Group, China) or mouse anti-BrdU antibody (1:400, DAKO Denmark) at $4^{\circ} \mathrm{C}$ overnight. For negative control, antibodies were replaced by homologous serum. Sectionswere washed with PBS and subsequently incubated with goat anti-mouse EnVision kit (DAKO Denmark) at room temperature. Peroxidase activity was detected using 3'3'diaminobenzidine tetrahydrochloride (DAB, DAKO Denmark) and counterstained with haematoxylin (Sigma-Aldrich MO USA). Digital images were prepared by Digital Sight ACT-1 for L-1 Software (Nikon Japan). Positively stained cells were counted as described previously with slight changes [30,45]. In brief, BrdU positive cells and hepatic progenitor cells positive for Pan-CK were counted in 20 adjacent non-overlapping fields in one section, at $400 \times$ magnification. 5 non-serial sections were counted for each rat. The expression of follistatin and activinA were annualized as described previously [46]. In brief, average value of IOD was obtained by analyzing five fields at $200 \times$ magnification per slide with Image-Pro Plus software (V.5.0).

\section{Real-time PCR}

Total RNA was extracted from liver tissue sample using Trizol regent (Invitrogen, CA USA) according to manufacturer's directions. Equal amounts of RNA were used for generation of first strand cDNA using PrimeScript ${ }^{\circ}$ RT reagent Kit (Takara Bio Inc, Japan). Primers used to detect activin $\beta$ A [Gene Bank: NM_017128.2], follistatin [Gene Bank: NM_012561.1] and $\beta$-actin were designed using the primer design software 'Primer 5.0' (Table 1) and purchase from suppliers (Invitrogen, CA USA). Real-Time PCR was performed on ABI Prism 7000 Sequence Detection System with ABI Prism 7000 SDS Software 1.0 in 96-well format and $25 \mu \mathrm{L}$ reaction volume per well (Applied Biosystems, CA USA) with SYBR Green Real-time PCR Master MixPLUS (TOYOBO, Japan) according to the manufacturers' introductions. The $\mathrm{Ct}$ values of the selected genes were first normalized with $\beta$-actin from the same sample, and then the relative expression of each gene was analyzed using $2^{-\Delta \Delta \mathrm{Ct}}$ Method.

\section{Cell culture}

Hepatic progenitor cell line LE6, derived from rats that were maintained on a choline-deficient diet for 6 weeks [47-49], were a kind gift from Prof. Nelson Fausto. Cells were grown in DMEM/F10 (Thermo Scientific HyClone, Utah USA) supplemented with $10 \%$ fetal bovine serum (FBS, Thermo Scientific HyClone, Utah USA), $0.5 \mathrm{mg} / \mathrm{L}$ insulin, $1 \mathrm{mg} / \mathrm{L}$ hydrocortisone (Sigma-Aldrich, MO USA) and $50 \mathrm{mg} / \mathrm{L}$ gentamicin(Invitrogen, CA USA) (LE medium) and were cultured in $37^{\circ} \mathrm{C}$ and $5 \%$ carbon dioxide.

Table 1 The primer sequences and melting temperature(Tm) of the examined genes

\begin{tabular}{llll}
\hline Gene & Sense & Antisense & Tm $^{\circ} \mathbf{C}$ \\
\hline Activin $\beta A$ & 5'-TGATGTGCGGATTGCTTGTG-3' & 5'-ACTGCGGTGAGGATGGTCTT-3' & 60 \\
Follistatin & 5'-AGCTTGCTGGGCAGATCCATT-3' & 5'-TACAGACGGGCTCATCCGACTT-3' & 60 \\
\hline
\end{tabular}


Table 2 Target sequences of specific shRNA oligoes to rat smad4

\begin{tabular}{llll}
\hline Marker & Gene & Target sequence & GC\% \\
\hline Sh1 & Smad4 & GCTACTTACCACCATAACA & $42.10 \%$ \\
Sh2 & Smad4 & GGTAGGAGAGACATTTAAA & $36.84 \%$ \\
Sh3 & Smad4 & GGAGTGCAGTTGGAGTGTA & $52.63 \%$ \\
Sh4 & Smad4 & GCTGAAAGAGAAGAAAGAT & $36.84 \%$ \\
\hline
\end{tabular}

\section{Lentivirus transfection of LE6 Cells}

Rat Smad4-specific shRNA lentivirus and random shRNA lentivirus were purchased from GeneChem Co Shanghai China (Table 2) [Gene Bank: NM_019275]. LE6 cells were incubated with Smad4-specific shRNA lentivirus particles at a ratio of 25 particles to 1 cell, in the presence of $8 \mu \mathrm{g} / \mathrm{ml}$ hexadimethrine bromide to improve transduction efficiency. Random oligo shRNA lentivirus was used as control. Stable Smad4 knock down LE6 cells were selected by $2 \mathrm{ug} / \mathrm{ml}$ puromycin. Smad4 knockdown effects from four
shRNA sequences were detected by western-blot and the most efficient sequence was used for further research.

Activin A and TGF- $\beta 1$ enzyme-linked immunosorbent assay Supernatants were collected from confluent LE6 cells treated with or without activin A and tested in triplicate for activin A and TGF- $\beta 1$ concentrations using rat activin A ELISA kit and rat TGF- $\beta 1$ ELISA kit (R\&D system, MN USA). 3 independent assays were performed with at least 3 replicates.

\section{Proliferation and apoptosis assay}

Growth property of LE6 cells was tested by CCK-8 assay according to manufacturer's introductions (Beyotime Institute of Biotechnology, China). Briefly, LE6 cells were seeded in triplicates in 96-well plate at 800 cells/100ul LE medium. Cells were either stimulated with or without various concentrations of activin A (PeproTech Inc, NJ USA), follistatin (R\&D system, MN USA) or activin A

Table 3 Primary antibodies used for western-blot

\begin{tabular}{|c|c|c|}
\hline Primary antibodies & Dilusion & Manufacture \\
\hline Rabbite anti-p-samd2(Ser465/467) & $1: 1000$ & Cell Signaling Technology, USA \\
\hline Rabbite anti-smad2 & $1: 1000$ & Cell Signaling Technology, USA \\
\hline Rabbite anti-p-samd3(ser423/425) & $1: 1000$ & Cell Signaling Technology, USA \\
\hline Rabbite anti-smad3 & $1: 1000$ & Cell Signaling Technology, USA \\
\hline Rabbite anti-smad4 & $1: 1000$ & Epitomics, China \\
\hline Mouse anti-samd2/3 & & Santa Cruz Biotechnology Inc, USA \\
\hline For WB & $1: 1000$ & \\
\hline For IP & $1: 50$ & \\
\hline Rabbite anti-p-ERK1/2(Thr202/Tyr204) & $1: 1000$ & Cell Signaling Technology, USA \\
\hline Mouse anti-ERK1/2 & $1: 2000$ & Cell Signaling Technology, USA \\
\hline Rabbite anti-p-JNK1/2(Thr183/Tyr185) & $1: 1000$ & Cell Signaling Technology, USA \\
\hline Rabbite anti-JNK1/2 & $1: 1000$ & Cell Signaling Technology, USA \\
\hline Rabbite anti-p-p38(Thr180/Tyr182) & $1: 1000$ & Cell Signaling Technology, USA \\
\hline Rabbite anti-p38 & $1: 1000$ & Cell Signaling Technology, USA \\
\hline Rabbite anti-p-Rb(Ser807/811) & $1: 1000$ & Cell Signaling Technology, USA \\
\hline Rabbite anti-Rb & $1: 1000$ & Santa Cruz Biotechnology Inc, USA \\
\hline Rabbite anti-p21 & $1: 1000$ & Epitomics, China \\
\hline Rabbite anti-p15 & $1: 1000$ & Epitomics, China \\
\hline Rabbite anti-p27 & $1: 1000$ & Cell Signaling Technology, USA \\
\hline Rabbite anti-cyclinD1 & $1: 5000$ & Epitomics, China \\
\hline Mouse anti-cyclinA & $1: 500$ & Boster, China \\
\hline Rabbite anti-cyclinE & $1: 500$ & Biolegend, USA \\
\hline Rabbite anti-CDK2 & $1: 500$ & Santa Cruz Biotechnology Inc, USA \\
\hline Rabbite anti-CDK4 & $1: 500$ & Santa Cruz Biotechnology Inc, USA \\
\hline Mouse anti-GAPDH & $1: 10000$ & Santa Cruz Biotechnology Inc, USA \\
\hline Mouse anti- $\beta$-actin & $1: 2000$ & Santa Cruz Biotechnology Inc, USA \\
\hline Mouse anti-laminB & $1: 500$ & Proteintech Group, USA \\
\hline
\end{tabular}


(200 ng/ml) plus follistatin (400 ng/ml). After 72 hours incubation at $37^{\circ} \mathrm{C}$, cell viability was determined by colorimetric assay using CCK-8. 3 independent assays were performed with at least 3 replicates.

For BrdU incorporation assay, LE6 cells were planted in triplicate in 6 -well-plate at $1.5 \times 105$ cells/well. Cells were incubated with activin A $(200 \mathrm{ng} / \mathrm{ml})$, follistatin (400 ng/ml) or activin A (200 ng/ml) plus follistatin (400 ng/ml) for 72 hours and 10uM BrdU (SigmaAldrich, MO USA) were added at the last $30 \mathrm{~min}$. Cells were harvested and fixed by ice cold $70 \%$ ethanol. After treated with $4 \mathrm{~N} \mathrm{HCL}$ and $0.2 \mathrm{M}$ borax, cells were incubated with mouse anti-BrdU monoclonal antibody (1:100, Santa Cruz Biotechnology, CA USA) for 1 hour at $4^{\circ} \mathrm{C}$ and FITC labeled goat anti-mouse antibody (1:100, Jackson ImmunoResearch Laboratories Inc, PA USA) for 1 hour at $37^{\circ} \mathrm{C}$. Then $\mathrm{BrdU}$ incorporation rate was examined by BD FACSCanto ${ }^{\text {Tn }}$ Flow Cytometry System (Becton, Dickinson and Company, NJ USA). For apoptosis assay, LE6 cells were incubated with indicated cell factors for 4 days, and then the cells were harvested and stained by FITC-labeled Annexin V/PI apoptosis assay kit (KeyGEN Biotech, China). The degree of apoptosis was tested by FACS. 3 independent assays were performed with at least 3 replicates.

\section{Western blotting and co-immunoprecipitation}

After treatment with indicated cell factors, LE6 cells or LE6-shSmad4 cells were harvested and incubated in icecold RIPA lysis (Beyotime Institute of Biotechnology, China) plus protein inhibitor cocktail (Roche Ltd, Switzerland) for whole cell protein, and NE-PER Nuclear and Cytoplasmic Extraction Reagents (Thermo Fisher Scientific Inc, MA USA) for nuclear and cytoplasmic fractionation. Then the protein content was detected by BCA kit (Thermo Fisher Scientific Inc, MA USA). 60ug lysate was run on $15 \%$ or $10 \%$ PAGE polyacrylamide gel, transferred onto PVDF membranes (Roche Ltd, Switzerland). After blocked in 5\% BSA in TBS at room temperature for 1 hour, the membranes were incubated with primary antibody at $4^{\circ} \mathrm{C}$ overnight. The details of primary antibodies were showen in Table 3 . Then the membranes were washed with $0.1 \%$ tween-20 in TBS (TBST) and incubated with horseradish peroxidase-conjugated secondary or alkaline phosphatase antibody secondary antibody at $37^{\circ} \mathrm{C}$ for 1 hours (1:5000, Jackson Immuno Research Laboratories Inc, PA USA). Then the membranes were washed with TBST 3 times for 45 mins. Protein band immunoreactivity was revealed by chemiluminescence according to the manufacturer's instructions (Thermo Fisher Scientific Inc, MA USA) and detected using an Alpha Innotech Fluorochem Imaging system (Alphatron Asia Pte Ltd, Singapore).
For co-immunoprecipitation, LE6 cells or LE6-shSamd4 cells were serum-starved for 12 hours, and then treated with $200 \mathrm{ng} / \mathrm{ml}$ activin A for 1 hour. Cells were harvested and incubated with IP-lysis buffer (Beyotime Institute of Biotechnology, China). Cell lysis were incubated with mouse anti-Smad2/3 polyclonal antibody (1:50, Santa Cruz Biotechnology, CA USA) at $4^{\circ} \mathrm{C}$ for 2 hours, followed by incubation with 20ul protein A/G agarose (Santa Cruz Biotechnology, CA USA) at $4^{\circ} \mathrm{C}$ overnight. Immunoprecipitates were washed 4 times with the lysis buffer and analysis by immunoblot using rat anti-Smad4 monoclonal antibody (1:2000, Epitomics, CA USA).

\section{Statistical analyses}

Data were expressed as mean values \pm standard deviation. The related expression of genes was log transformed and variation with time assessed by ANOVA. The data of AnnexinV/PI assay, BrdU incorporation assay (both FACS and immunohistochemistry, except for Figure $5 \mathrm{~B}$ ) and liver/body weight ratio were analyzed by student's t-test. ELISA, cell viability data and BrdU incorporation data (Figure $5 \mathrm{~B}$ ) were analyzed by unpaired student's t-test or ANOVA by SPSS 11.5. A difference in $P$ values of $<0.05$ was considered significant.

\section{Abbreviation \\ MAPK: Mitogen activated protein kinase; 2-AAF: 2-acetylaminofuorene; $\mathrm{PH}$ : Partial hepatectomy; TGF- $\beta$ : Transforming growth factor $\beta$; ActR II A/ B: Activin type II receptor A/B; ALK4: Activin A receptor-like kinase 4; CCK-8: Cell counting kit-8; R-smad: Receptor-regulated smad; co-smad: Common mediator Smad; pan-CK: Pan-cytokeratin; HPC: Hepatic progenitor cell; CDK: Cyclin-dependent kinase; HGF: Hepatocyte growth factor; EGF: Epithelial growth factor; BrdU: 5-bromo-2 -deoxyuridine; Ct: Cycle threshold.}

\section{Competing interest}

The authors confirm that there is no competing of interest.

\section{Authors' contribution}

LC: Did major experiments, animal model and acquisition of data, analysis and interpretation of data and drafted the manuscript. WZ: Participated in research design and animal experiment, acquisition of data and involved in drafting the manuscript. HfL: participated in research design, carried out immunohistochemistry assay, flow Cytometry assay, technique support, and helped to draft the manuscript. QdZ: Carried out the western blot assay, co-IP assay and helped to draft the manuscript. ZyD: Participated in cell culture, animal experiment and acquisition of some data. HqY: Participated in animal experiment, helped to analyses data. WbL: Participated in immunohistochemistry and acquisition of few data. YhW: Participated in western blot and IP assay and acquisition of few data. QM: Participated in lentivirus transfection and acquisition of few data. BxZ: Participated in research design and technique support. XpC: Study concept and design, analysis and interpretation of data, drafted the final manuscript, critical revision of manuscript for important intellectual content, technical support and study supervision. All authors read and approved the final manuscript.

\section{Acknowledgements}

This work was supported by Grants from National Natural Science Foundation of China (NO.30872499), 81300575, 81372495, 81372327 and 81202300 ) and the state key project on inflectional disease of China (Grant No.2008ZX1002-25, 2012ZX10002016-004 and 2012ZX10002010-001-004). We thank Prof. Nelson Fausto for providing LE6 cell line and Prof. Itaru Kojima for technique assistance on follistatin administration in vivo. We thank Dr. Arian Laurence for the great help in the language of the manuscript. 


\section{Author details}

${ }^{1}$ Hepatic surgery centre, Tongji Medical College, Tongji Hospital, Huazhong University of Science and Technology, Wuhan, China. ${ }^{2}$ Department of Nephrology, Tongji Medical College, Tongji Hospital, Huazhong University of Science and Technology, Wuhan, China. ${ }^{3}$ Department of Hepatobiliary Surgery, First Affiliated Hospital, Medical College of Shihezi University, Shihezi, China.

Received: 18 November 2013 Accepted: 8 March 2014 Published: 17 March 2014

\section{References}

1. Sangan CB, Tosh D: Hepatic progenitor cells. Cell Tissue Res 2010, 342:131-137.

2. Tanaka M, Itoh T, Tanimizu N, Miyajima A: Liver stem/progenitor cells: their characteristics and regulatory mechanisms. J Biochem 2011, 149:231-239.

3. Laishes BA, Rolfe PB: Search for endogenous liver colony-forming units in F344 rats given a two-thirds hepatectomy during short-term feeding of 2-acetylaminofluorene. Cancer Res 1981, 41:1731-1741.

4. Paku S, Nagy P, Kopper L, Thorgeirsson SS: 2-acetylaminofluorene dosedependent differentiation of rat oval cells into hepatocytes: confocal and electron microscopic studies. Hepatology 2004, 39:1353-1361.

5. Park DY, Suh KS: Transforming growth factor-beta1 protein, proliferation and apoptosis of oval cells in acetylaminofluorene-induced rat liver regeneration. J Korean Med Sci 1999, 14:531-538.

6. Erker L, Grompe M: Signaling networks in hepatic oval cell activation. Stem Cell Res 2007, 1:90-102.

7. Michalopoulos GK: Liver regeneration after partial hepatectomy: critical analysis of mechanistic dilemmas. Am J Pathol 2010, 176:2-13.

8. Sanchez A, Fabregat I: Growth factor- and cytokine-driven pathways governing liver stemness and differentiation. World J Gastroenterol 2010, 16:5148-5161

9. Nguyen LN, Furuya MH, Wolfraim LA, Nguyen AP, Holdren MS, Campbell JS, Knight B, Yeoh GC, Fausto N, Parks WT: Transforming growth factor-beta differentially regulates oval cell and hepatocyte proliferation. Hepatology 2007, 45:31-41.

10. del Castillo G, Factor VM, Fernandez M, Alvarez-Barrientos A, Fabregat I, Thorgeirsson SS, Sanchez A: Deletion of the Met tyrosine kinase in liver progenitor oval cells increases sensitivity to apoptosis in vitro. Am J Pathol 2008, 172:1238-1247.

11. Preisegger $\mathrm{KH}$, Factor VM, Fuchsbichler A, Stumptner C, Denk H, Thorgeirsson SS: Atypical ductular proliferation and its inhibition by transforming growth factor beta1 in the 3,5-diethoxycarbonyl-1,4dihydrocollidine mouse model for chronic alcoholic liver disease. Lab Invest 1999, 79:103-109.

12. Oe S, Lemmer ER, Conner EA, Factor VM, Leveen P, Larsson J, Karlsson S, Thorgeirsson SS: Intact signaling by transforming growth factor beta is not required for termination of liver regeneration in mice. Hepatology 2004, 40:1098-1105.

13. Xia Y, Schneyer AL: The biology of activin: recent advances in structure, regulation and function. J Endocrinol 2009, 202:1-12.

14. Kogure K, Omata W, Kanzaki M, Zhang YQ, Yasuda H, Mine T, Kojima I: A single intraportal administration of follistatin accelerates liver regeneration in partially hepatectomized rats. Gastroenterology 1995, 108:1136-1142.

15. Kogure K, Zhang YQ, Shibata H, Kojima I: Immediate onset of DNA synthesis in remnant rat liver after $90 \%$ hepatectomy by an administration of follistatin. J Hepatol 1998, 29:977-984.

16. Kogure K, Zhang YQ, Kanzaki M, Omata W, Mine T, Kojima I: Intravenous administration of follistatin: delivery to the liver and effect on liver regeneration after partial hepatectomy. Hepatology 1996, 24:361-366.

17. Endo D, Maku-Uchi M, Kojima I: Activin or follistatin: which is more beneficial to support liver regeneration after massive hepatectomy? Endocr J 2006, 53:73-78.

18. Kofman AV, Morgan G, Kirschenbaum A, Osbeck J, Hussain M, Swenson S, Theise ND: Dose- and time-dependent oval cell reaction in acetaminopheninduced murine liver injury. Hepatology 2005, 41:1252-1261.

19. Kuwahara R, Kofman AV, Landis CS, Swenson ES, Barendswaard E, Theise ND: The hepatic stem cell niche: identification by label-retaining cell assay. Hepatology 2008, 47:1994-2002.

20. Jelnes P, Santoni-Rugiu E, Rasmussen M, Friis SL, Nielsen JH, Tygstrup N, Bisgaard HC: Remarkable heterogeneity displayed by oval cells in rat and mouse models of stem cell-mediated liver regeneration. Hepatology 2007, 45:1462-1470.

21. Pichard $V$, Aubert $D$, Ferry $N$ : Direct in vivo cell lineage analysis in the retrorsine and 2AAF models of liver injury after genetic labeling in adult and newborn rats. PLoS One 2009, 4:e7267.

22. Massague J: TGFbeta in Cancer. Cell 2008, 134:215-230.

23. Kanamaru C, Yasuda H, Fujita T: Involvement of Smad proteins in TGF-beta and activin A-induced apoptosis and growth inhibition of liver cells. Hepatology Res 2002, 23:211-219.

24. Takamura K, Tsuchida K, Miyake H, Tashiro S, Sugino H: Activin and activin receptor expression changes in liver regeneration in rat. $J$ Surg Res 2005, 126:3-11.

25. Gold EJ, Zhang X, Wheatley AM, Mellor SL, Cranfield M, Risbridger GP, Groome NP, Fleming JS: betaA- and betaC-activin, follistatin, activin receptor $m R N A$ and betaC-activin peptide expression during rat liver regeneration. J Mol Endocrinol 2005, 34:505-515.

26. Takabe K, Wang L, Leal AM, Macconell LA, Wiater E, Tomiya T, Ohno A Verma IM, Vale W: Adenovirus-mediated overexpression of follistatin enlarges intact liver of adult rats. Hepatology 2003, 38:1107-1115.

27. Medina J, Yamada S, Kojima I: Identification of differentially expressed genes during proliferative response of the liver induced by follistatin. Endocr J 2009, 56:1067-1077.

28. Kogure K, Zhang YQ, Maeshima A, Suzuki K, Kuwano H, Kojima I: The role of activin and transforming growth factor-beta in the regulation of organ mass in the rat liver. Hepatology 2000, 31:916-921.

29. Ooe H, Chen Q, Kon J, Sasaki K, Miyoshi H, Ichinohe N, Tanimizu N, Mitaka T: Proliferation of rat small hepatocytes requires follistatin expression. J Cell Physiol 2012, 227:2363-2370.

30. Xiang S, Dong HH, Liang HF, He SQ, Zhang W, Li CH, Zhang BX, Zhang BH, Jing K, Tomlinson S, van Rooijen N, Jiang L, Cianflone K, Chen XP: Oval cell response is attenuated by depletion of liver resident macrophages in the 2-AAF/partial hepatectomy rat. PLoS One 2012, 7:e35180.

31. Ichinohe N, Tanimizu N, Ooe H, Nakamura Y, Mizuguchi T, Kon J, Hirata K, Mitaka T: Differentiation capacity of hepatic stem/progenitor cells isolated from D-galactosamine-treated rat livers. Hepatology 2013, 57:1192-1202

32. Kon J, Ichinohe N, Ooe H, Chen Q, Sasaki K, Mitaka T: Thy1-positive cells have bipotential ability to differentiate into hepatocytes and biliary epithelial cells in galactosamine-induced rat liver regeneration. Am J Pathol 2009, 175:2362-2371.

33. Menthena A, Koehler Cl, Sandhu JS, Yovchev MI, Hurston E, Shafritz DA, Oertel M: Activin A, p15INK4b signaling, and cell competition promote stem/progenitor cell repopulation of livers in aging rats. Gastroenterology 2011, 140:1009-1020.

34. Burdette JE, Jeruss JS, Kurley SJ, Lee EJ, Woodruff TK: Activin A mediates growth inhibition and cell cycle arrest through Smads in human breast cancer cells. Cancer Res 2005, 65:7968-7975.

35. Ho J, de Guise C, Kim C, Lemay S, Wang XF, Lebrun JJ: Activin induces hepatocyte cell growth arrest through induction of the cyclindependent kinase inhibitor p15INK4B and Sp1. Cell Signal 2004, 16:693-701.

36. Zauberman A, Oren M, Zipori D: Involvement of p21(WAF1/Cip1), CDK4 and $\mathrm{Rb}$ in activin A mediated signaling leading to hepatoma cell growth inhibition. Oncogene 1997, 15:1705-1711.

37. Pardali K, Kowanetz M, Heldin CH, Moustakas A: Smad pathway-specific transcriptional regulation of the cell cycle inhibitor p21(WAF1/Cip1). J Cell Physiol 2005, 204:260-272.

38. Razanajaona D, Joguet S, Ay AS, Treilleux I, Goddard-Leon S, Bartholin L, Rimokh R: Silencing of FLRG, an antagonist of activin, inhibits human breast tumor cell growth. Cancer Res 2007, 67:7223-7229.

39. Chen YG, Wang Q, Lin SL, Chang CD, Chuang J, Ying SY: Activin signaling and its role in regulation of cell proliferation, apoptosis, and carcinogenesis. Exp Biol Med 2006, 231:534-544.

40. Huang J, Bi Y, Zhu GH, He Y, Su Y, He BC, Wang Y, Kang Q, Chen L, Zuo GW, Luo Q, Shi Q, Zhang BQ, Huang A, Zhou L, Feng T, Luu HH, Haydon RC, He TC, Tang N: Retinoic acid signalling induces the differentiation of mouse fetal liver-derived hepatic progenitor cells. Liver Int 2009, 29:1569-1581.

41. Cocolakis E, Lemay S, Ali S, Lebrun JJ: The p38 MAPK pathway is required for cell growth inhibition of human breast cancer cells in response to activin. J Biol Chem 2001, 276:18430-18436. 
42. Chen W, Woodruff TK, Mayo KE: Activin A-induced HepG2 liver cell apoptosis: involvement of activin receptors and smad proteins. Endocrinology 2000, 141:1263-1272.

43. Phillips DJ, de Kretser DM, Hedger MP: Activin and related proteins in inflammation: not just interested bystanders. Cytokine Growth Factor Rev 2009, 20:153-164.

44. Zhang W, Chen XP, Zhang WG, Zhang F, Xiang S, Dong HH, Zhang L: Hepatic non-parenchymal cells and extracellular matrix participate in oval cellmediated liver regeneration. World J Gastroenterol 2009, 15:552-560.

45. Lim R, Knight B, Patel K, McHutchison JG, Yeoh GC, Olynyk JK: Antiproliferative effects of interferon alpha on hepatic progenitor cells in vitro and in vivo. Hepatology 2006, 43:1074-1083.

46. Hou J, Xu J, Jiang R, Wang Y, Chen C, Deng L, Huang X, Wang X, Sun B: Estrogen-sensitive PTPRO expression represses hepatocellular carcinoma progression by control of STAT3. Hepatology 2013, 57:678-688.

47. Yaswen $P$, Hayner NT, Fausto N: Isolation of oval cells by centrifugal elutriation and comparison with other cell types purified from normal and preneoplastic livers. Cancer Res 1984, 44:324-331.

48. Braun L, Goyette M, Yaswen P, Thompson NL, Fausto N: Growth in culture and tumorigenicity after transfection with the ras oncogene of liver epithelial cells from carcinogen-treated rats. Cancer Res 1987, 47:4116-4124.

49. Lazaro CA, Rhim JA, Yamada Y, Fausto N: Generation of hepatocytes from oval cell precursors in culture. Cancer Res 1998, 58:5514-5522.

doi:10.1186/1478-811X-12-18

Cite this article as: Chen et al:: Activin $\mathrm{A}$ induces growth arrest through a SMAD- dependent pathway in hepatic progenitor cells. Cell Communication and Signaling 2014 12:18.

\section{Submit your next manuscript to BioMed Central and take full advantage of:}

- Convenient online submission

- Thorough peer review

- No space constraints or color figure charges

- Immediate publication on acceptance

- Inclusion in PubMed, CAS, Scopus and Google Scholar

- Research which is freely available for redistribution 